\title{
In vivo characterization of the BLV miRNA cluster
}

\author{
Anthony Rodari ${ }^{1 \dagger}$, Benoît Van Driessche ${ }^{1 \dagger}$, Nadège Delacourt ${ }^{1}$, Caroline Vanhulle ${ }^{1}$, Arsène Burny ${ }^{2}$, \\ Anne Van den Broeke ${ }^{2,3}$, Olivier Rohr ${ }^{4}$, Carine Van Lint ${ }^{{ }^{*}}$ \\ From 17th International Conference on Human Retroviruses: HTLV and Related Viruses \\ Trois Ilets, Martinique. 18-21 June 2015
}

Bovine leukemia virus (BLV), a B-lymphotropic oncogenic retrovirus sharing common biological and structural features with the human T-cell leukemia virus I and II (HTLV-I and II), is the etiologic agent of enzootic bovine leucosis. One major feature of the BLV infection is the absence of viremia. It is widely accepted that BLV latency, due to the RN! polymerase II 5'-LTR-driven transcriptional and epigenetic repression is a viral strategy to escape from the host immune system and allow tumor development. Recently, it has been demonstrated by deep sequencing and bioinformatics analysis that the BLV genome encodes a cluster of micro-RNAs which is predicted to be transcribed by RNA polymerase III suggesting that the silencing dogma in BLV transcriptional regulation is only partially correct. Here, we demonstrated by chromatin immunoprecipitation assays that BLV miRNAs were indeed transcribed in vivo by RNA polymerase III through a type II RNAPIII promoter similar to the one directing tRNAs transcription. We also showed that an activating epigenetic environment surrounds the miRNAs cluster. Overall, our results provide new insights into a better understanding of the molecular mechanisms regulating gene expression of oncogenic retroviruses.
doi:10.1186/1742-4690-12-S1-011

Cite this article as: Rodari et al:: In vivo characterization of the BLV miRNA cluster. Retrovirology 2015 12(Suppl 1):011.

\section{Authors' details \\ ${ }^{1}$ Service of Molecular Virology, University of Brusells (ULB), Gosselies, Belgium. ${ }^{2}$ Laboratory of Experimental Hematology, Institut Jules Bordet, University of Brusells (ULB), Brusells, Belgium. ${ }^{3}$ Unit of Animal Genomics, GIGA, University of Liège (ULg), Liège, Belgium. ${ }^{4}$ Institut Universitaire de Technologie (IUT) Louis Pasteur de Schiltigheim, Université of Strasbourg, Schiltigheim, France.}

Published: 28 August 2015

\footnotetext{
* Correspondence: cvlint@ulb.ac.be

† Contributed equally

${ }^{1}$ Service of Molecular Virology, University of Brusells (ULB), Gosselies, Belgium Full list of author information is available at the end of the article
}

Submit your next manuscript to BioMed Central and take full advantage of:

- Convenient online submission

- Thorough peer review

- No space constraints or color figure charges

- Immediate publication on acceptance

- Inclusion in PubMed, CAS, Scopus and Google Scholar

- Research which is freely available for redistribution

Submit your manuscript at www.biomedcentral.com/submit

\section{() Biomed Central}

\section{Biomed Central}

(c) 2015 Rodari et al. This is an Open Access article distributed under the terms of the Creative Commons Attribution License (http:// creativecommons.org/licenses/by/4.0), which permits unrestricted use, distribution, and reproduction in any medium, provided the original work is properly cited. The Creative Commons Public Domain Dedication waiver (http://creativecommons.org/publicdomain/ zero/1.0/) applies to the data made available in this article, unless otherwise stated. 